\title{
Identification and characterization of iron reducing bacteria attached on stainless steel immersed in Port Dickson seawater
}

\author{
Muhammad Izzuddin B. Nasruddin ${ }^{1}$, Fathul Karim B. Sahrani ${ }^{1}$, Asmat Bt. Ahmad ${ }^{2 *}$ \\ ${ }^{1}$ School of Environment and Natural Resource, Faculty of Science and Technology, Universiti Kebangsaan Malaysia, \\ 43600 UKM Bangi, Selangor, Malaysia. \\ ${ }^{2}$ School of Bioscience and Biotechnology, Faculty of Science and Technology, Universiti Kebangsaan Malaysia, 43600 \\ UKM Bangi, Selangor, Malaysia. \\ Email: asmat@ukm.my
}

Received 8 October 2013; Received in revised form 23 December 2013; Accepted 9 January 2014

\begin{abstract}
Aims: The study focused on the isolation, identification and characterization of iron reducing bacteria (IRB) attached on stainless steel immersed in seawater.

Methodology and results: Ten marine bacteria were successfully isolated from 5 different stainless steel samples immersed in seawater of Port Dickson, Negeri Sembilan. These bacteria were cultured in VMNI medium for $72 \mathrm{~h}$ at 37 ${ }^{\circ} \mathrm{C}$ and pure colonies of 10 isolates were obtained and later were used for molecular analysis. The biofilm of each strains were observed by using microscope Scanning Electron Microscope (SEM) with magnification of 3000x and 5000x and most of these bacterial cells are in a form of bacillus, coccobacillus, coccus and dicoccus. By using polymerase chain reaction (PCR), genome from 10 strains were used to amplify the $16 \mathrm{~S}$ rRNA gene sequence and aligned using the multiple alignments software, Mega 4 Software. The phylogenetic analysis which based on the 16S rRNA sequences revealed that 6 out of 10 strains were belong to the Shewanella genus while the other two strains were put under the family of Alteromonodaceae and Rhodobacteraceae and one strain was not determined yet because of no accurate data from GenBank and was known as unidentified organism.

Conclusion, significance and impact study: Six out of ten strains isolated are belong to Shewanella genus which was one of iron-reducing bacteria group and by using SEM, biofilm formation and bacterial cells can be observed. IRB's role in biocorrosion are important for several sectors such as oil and gas and shipping industry and therefore, this study was undertaken to isolate, identify and perform initial characterization on IRB.
\end{abstract}

Keywords: Marine bacteria, biofilm, 16S rRNA, Shewanella sp.

\section{INTRODUCTION}

Microbiologically Influenced Corrosion (MIC) or biocorrosion is an electrochemical process where microorganisms involves to initiate, stimulate or accelerate the corrosion process without changing the electrochemical conditions of the material (Videla, 1996). MIC occurs mostly on metals that submerged in water environments such as seas, rivers and lakes (Landoulsi, 2008). Among the microorganisms involved in the process of metal corrosion including sulfate reducing bacteria $(\mathrm{SRB})$, iron reducing bacteria (IRB), manganese and iron oxidizing bacteria $(\mathrm{I} / \mathrm{MOB})$ and methanogenesis (Walch, 1992). The ability of other microorganisms especially IRB in the corrosion process are negated because more focus being given to the role of SRB in MIC (Javaherdashti, 2008). There are two actions of IRB that promote the corrosion process, by lowering the insoluble ferric compounds to dissolved ferrous ion and subsequently removing the corrosion protective layer, thus promoting the formation of biofilm (Videla, 1996).
Iron reducing bacteria (IRB) is a group of bacteria that perform the reduction of iron and produce hydrogen gas and organic matter to gain energy for growth (Myers and Nealson, 1990; Lovely, 1991). Iron reduction can be define as the use of $\mathrm{Fe}(\mathrm{III})$ as the outermost electron acceptor in bacterial respiration and most of the process involves the conversion of iron from the ferric state to ferrous, hence the IRB with its unique process has been the subject for researcher and scientist (Lovely, 1991; Nealson and Saffarini, 1994). IRB are generally isolated from a variety of habitats and most studies are focus on genus Shewanella and Geobacter where Shewanella are commonly found in marine environment, freshwater, estuary and intertidal areas (Yoon et al. 2004; Yang et al., 2006). Besides its role in the mechanism of corrosion in metal, Shewanella responsible for the decomposition of organic material, involved with bioremediation of contaminated material, cracking of crude petroleum, reduction of magnesium and iron oxide and forming a thick of biofilm layer on stainless steel, which shows the importance of Shewanella in microbiological influenced 
corrosion (MIC) (Obuekwe et al., 1981; Semple and Westlake, 1987; Pukall et al., 2001; Nealson et al., 2002).

In Malaysia, there are no specific studies have been carried out regarding IRB, particularly the genus Shewanella. Up till now, there is no article or journal that focuses on IRB isolated from the marine environment of Malaysia. Given the importance of IRB in terms of industry, it is very important to provide baseline data for further research in the future. Therefore, this study was undertaken to isolate, identify and perform initial characterization on IRB.

\section{MATERIALS AND METHODS}

\section{Site description and sampling procedures}

Sampling was conducted twice which was in November 2009 and July 2010 in coastal area of Pasir Panjang, Port Dickson, Negeri Sembilan. The sampling has focused on the jetty area which consists of metals and mud that was located in tidal area. Corroded stainless steel were scratched by using sterile knife until a layer of black biofilm can be seen on the surface of the metal before the biofilm was transferred into universal bottle by using sterile cotton bud. Universal bottle then was filled with seawater until there is no space for air to prepare semi anaerobic condition. For lab work, $20 \%$ of the original sample in one universal bottle was transferred into other universal bottle before being added with VMNI solution. Samples then were kept in incubator at $37^{\circ} \mathrm{C}$.

\section{Isolation of pure cultures}

VMNI medium was used as an enrichment medium for the growth of isolated marine bacteria. VMNI medium contains metal traces and was proposed by Zinkevich et al. (1966) which has been modified from Postgate Marine $\mathrm{C}$ medium. The cells were grown anaerobically at $37^{\circ} \mathrm{C}$ for 3-7 days. The bacteria then was isolated into fresh medium by using streaking and pour plate technique to obtain pure culture that will be used for further analysis. Stock cultures then were stored at $4{ }^{\circ} \mathrm{C}$ and regularly transferred to fresh medium to maintain viability.

\section{Observation using Scanning Electron Microscope (SEM)}

Ten small sizes of stainless steels were immersed in 10 VMNI broths that were cultured with 10 isolates of IRB for $24 \mathrm{~h}$ at $37^{\circ} \mathrm{C}$. Stainless steel then was left for $24 \mathrm{~h}$ for IRB to attach and produce biofilms on its surface. Stainless steels were observed by using SEM with $3000 x$ and $5000 x$ magnification to observe the production of biofilm by IRB.

\section{Genomic DNA extraction}

A $1.5 \mathrm{~mL}$ sample of fully grown cell culture was pelletted by centrifugation at $8000 \mathrm{rpm}$ for $2 \mathrm{~min}$. The cell pellet was resuspended in $567 \mu \mathrm{L}$ TE buffer $(10 \mathrm{mM}$ Tris- $\mathrm{HCl}, 1$
mM EDTA, $\mathrm{pH}$ 8.0) before $30 \mu \mathrm{L}$ of sodium doedesyl sulfate $10 \%$ and $3 \mu \mathrm{L}$ Proteinase $\mathrm{K}$ were added to the cell pellet. The mixture then was incubated in waterbath at 37 ${ }^{\circ} \mathrm{C}$ for $1 \mathrm{~h}$. One hundred $\mu \mathrm{L}$ of $5 \mathrm{M} \mathrm{NaCl}$ was added to the mixture along with $80 \mu \mathrm{L}$ of CTAB solution before being incubated again in waterbath at $65^{\circ} \mathrm{C}$ for $10 \mathrm{~min}$. Next, $600 \mu \mathrm{L}$ of chloroform;isoamyl alcohol (C:I; 24:1) was added to the mixture before being centrifuged at 15000 $\mathrm{rpm}$ at $4{ }^{\circ} \mathrm{C}$ for $5 \mathrm{~min}$. Aqueous solution obtained was transferred into new Eppendorf tube before being added with $180 \mu \mathrm{L}$ isopropanol and was centrifuged at 15000 $\mathrm{rpm}$ at $4{ }^{\circ} \mathrm{C}$ for $15 \mathrm{~min}$. The supernatant was removed and the pellet leaves was added with $300 \mu \mathrm{L}$ of $70 \%$ ethanol before being centrifuged again at $15000 \mathrm{rpm}$ at 4 ${ }^{\circ} \mathrm{C}$ for $5 \mathrm{~min}$. The supernatant then was removed and DNA pellet leaves will be dried up for 30 min before being added with $30 \mu \mathrm{L}$ TE buffer. The extract product was run on agarose gel $1 \%$ in Tris-Borate-EDTA (TBE) buffer at $80 \mathrm{~V}$ for $1 \mathrm{~h}$. The agarose gel then was immersed in ethidium bromide (EtBr) for $10 \mathrm{~min}$ and deionized water for $10 \mathrm{~min}$ to decolorize. Gel then was observed by using gelCam camera (Polaroid,USA) under UV light.

\section{PCR amplification}

The mixture of PCR reaction includes $5 \mu \mathrm{L}$ of $10 \times \mathrm{PCR}$ buffer, $4 \mu \mathrm{L} \mathrm{MgCl}$, $1 \mu \mathrm{L}$ of dNTP, $35 \mu \mathrm{L}$ of $\mathrm{ddH}_{2} \mathrm{O}, 1 \mu \mathrm{L}$ of both universal primer for prokaryote 16SrRNA-F (5'AGAGTTTGATCCTGGCTCAG-3') and 16SrRNA-R (5'ACGGCTACCTTGTTACGACTT-3'), $2 \mu \mathrm{L}$ of Taq polymerase and $1 \mu \mathrm{L}$ of DNA genome. There are 3 processes in PCR including denaturation, annealing and elongation step. The first step was denaturation at $95{ }^{\circ} \mathrm{C}$ for $30 \mathrm{sec}$ followed by annealing process at $55^{\circ} \mathrm{C}$ for 30 $\mathrm{sec}$ and elongation process for $1 \mathrm{~min}$ at $72{ }^{\circ} \mathrm{C}$. All the processes have about 30 cycles and were concluded by final elongation at $72{ }^{\circ} \mathrm{C}$ for $10 \mathrm{~min}$. The PCR product was run on agarose gel $1 \%$ in Tris-Borate-EDTA (TBE) buffer at $80 \mathrm{~V}$ for $1 \mathrm{~h}$. The agarose gel then was immersed in $\mathrm{EtBr}$ for $10 \mathrm{~min}$ and deionized water for $10 \mathrm{~min}$ to decolorize. Gel then was observed by using gelCam camera (Polaroid,USA) under UV light.

\section{DNA purification}

PCR product was purified by using Promega DNA Purification Kit (according to manufacturer's instruction). 5 volume of binding buffer was added to 1 volume of PCR product in $1.5 \mathrm{~mL}$ tube before being transferred into purification tube and was centrifuged at $13,000 \mathrm{rpm}$ for 40 sec. Supernatant then was removed and $1.5 \mathrm{~mL}$ tube was added back into purification tube. Next, $750 \mu \mathrm{L}$ of PE buffer was added and centrifuged again at 13,000 rpm for $40 \mathrm{sec}$. Supernatant formed once again was removed and the mixture was centrifuged at the same speed for $1 \mathrm{~min}$ to make sure the tube was in a pure dried condition. Supernatant was removed and collector tube was replaced. After that, $50 \mu \mathrm{L}$ of $\mathrm{dd}_{2} \mathrm{O}$ was added in purification tube and was centrifuged at 13,000 rpm for 1 
min to obtain pure DNA genome. Supernatant formed then was submitted to First Base for DNA sequencing.

\section{Sequence analysis and phylogeny tree}

DNA sequences data result obtained from First Base were analyzed manually based on chromatogram by using MEGA 4 software. The DNA sequences then were compared with GenBank sequences by using BLAST software (http://www.ncbi.nlm.nih.gov). Phylogenetic analysis was done by using MEGA 4 software. Multiple alignments have been activated by using Clustal algorithm in Clustal-X program to see and compare DNA sequences with GenBank in order to build phylogeny tree (Thompson et al., 1997). Phylogeny tree was constructed using neighbor joining (NJ) method in the MEGA 4 software and tree topology was examined using 100 bootstrapped data sets.

\section{RESULTS}

After immersion of stainless steel for 3 days in VMNI broth that contained IRB culture, image from SEM shows bacterial cells in biofilm with 2000x and 5000x magnification. Most of these bacterial cells are in a form of bacillus, cocobacillus, coccus and dicoccus. The thickness of biofilm layer formed are depends on the concentration of IRB culture and also the maturity and fertility of IRB culture.

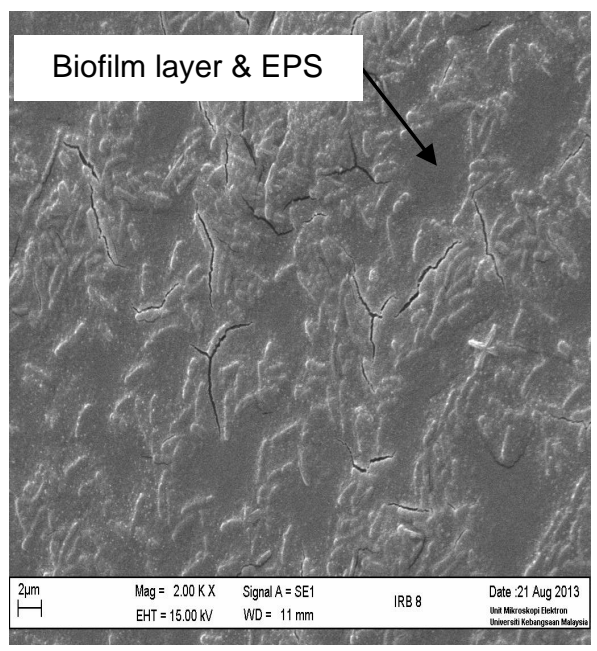

(a)

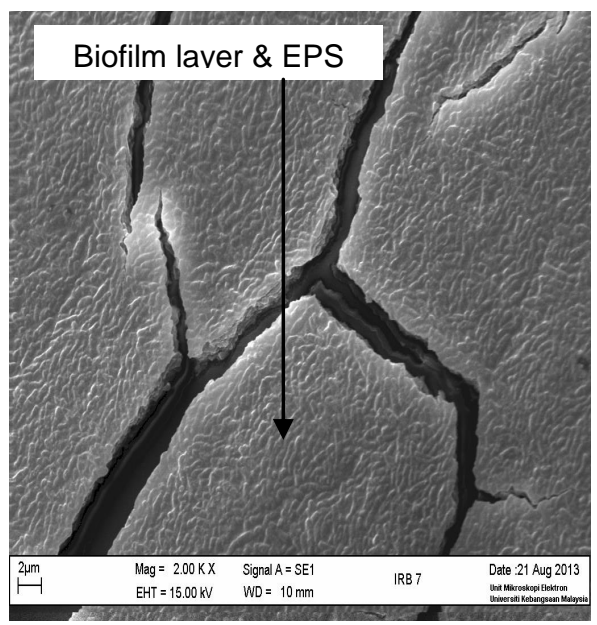

(c)

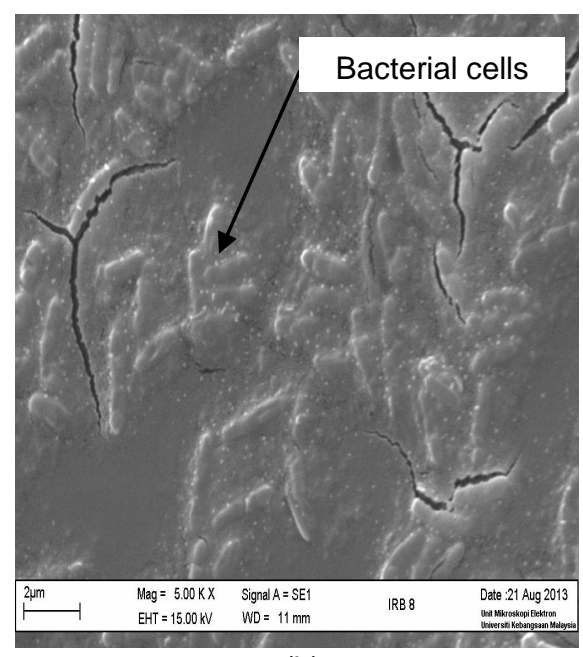

(b)

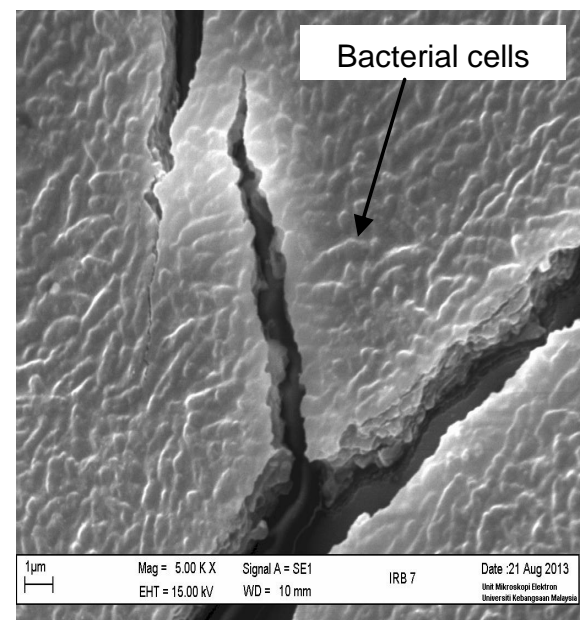

(d)

Figure 1: Bacterial cells and EPS production growth in biofilm observation using (a) and (c) 2000x magnification and (b) and (d) 5000x magnification of SEM. 
Ten isolates of marine bacteria genomic DNA has been successfully extracted and then was followed by PCR amplification by using primer $16 \mathrm{~S}$ rRNA. PCR product obtained was shown in figure 1.1 ranging $\sim 1500$ bp size and $1 \mathrm{~kb}$ DNA marker was put at the end of the gel to make it easier to identify the formed banned. Next PCR product was purified before being sent to for DNA sequence.

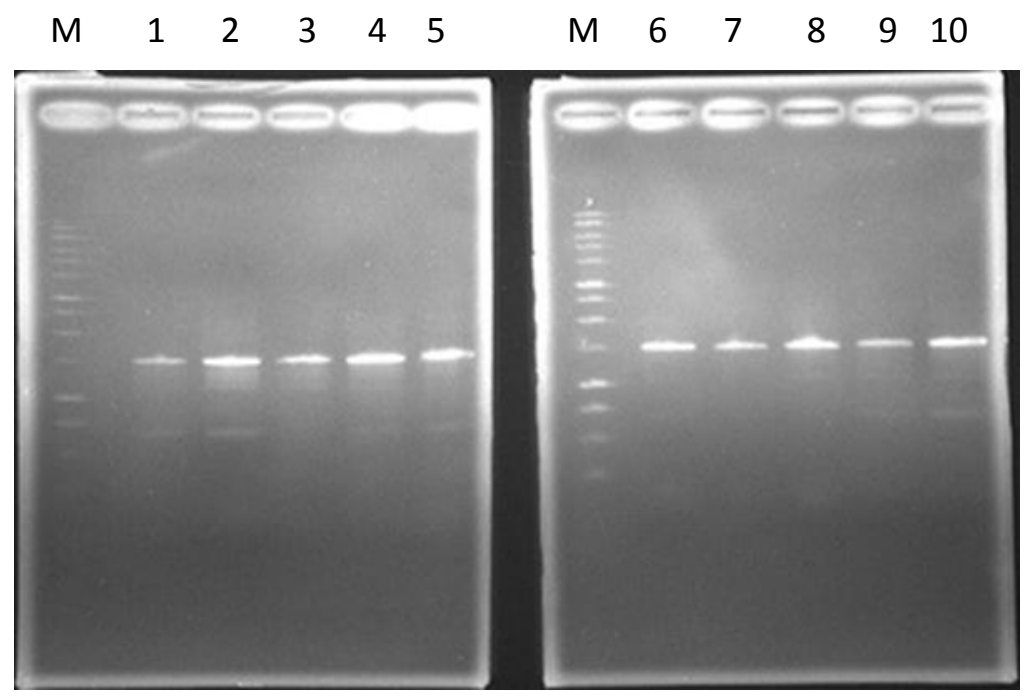

Figure 2: PCR products 1500 base pair for isolates from Port Dickson seawater. M, marker 1kb; 1, C1(2)(2); 2, E2B; 3, E3B; 4, C2(2); 5, C2(3); 6, 1A2H(1); 7, 1A2H(2); 8, A2; 9, F1S; 10, F5S.

Table 1: Comparison between isolates sequences with GenBank sequences based on percentage of similarity by using BLAST software.

\begin{tabular}{|c|c|c|c|}
\hline Isolates & Species from GenBank & Accession Number & Percentage Similarity \\
\hline $\mathrm{C} 22$ & Shewanella haliotis strain MS41 & FN997635 & 99 \\
\hline $\mathrm{A} 1$ & Shewanella haliotis strain MS32 & FN997635 & 99 \\
\hline E2B & Shewanella sp. MA667 & FR744875 & 98 \\
\hline E3B & Shewanella haliotis strain DW01 & HM016086 & 95 \\
\hline F1S & Shewanella sp. W3 & GQ280385 & 99 \\
\hline F5S & Rhodobacter capsulatus strain PSB-06 & FJ866784 & 99 \\
\hline $1 \mathrm{~A} 2 \mathrm{H} 2$ & Shewanella algae strain BPRIST 021 & JF431412 & 96 \\
\hline $1 \mathrm{~A} 2 \mathrm{H} 1$ & Alteromonodacea bacterium $\mathrm{PH} 39$ & AF513471 & 99 \\
\hline C122 & $\begin{array}{l}\text { Unidentified organism clone ctg- } \\
\text { NISA224 }\end{array}$ & DO396164 & 99 \\
\hline
\end{tabular}


DNA sequences obtained from First Base were compared with GenBank DNA sequences by using BLAST program (http://www.ncbi.nlm.nih.gov) and the result was shown in Table 1. Eight strains were identified successfully which 6 of them identified as Shewanella sp. which was belong to iron-reducing bacteria group. The comparison of marine bacteria DNA sequences with sequences in GenBank was also compiled with number series and maximum identification percent. All sequences give similarity between $95 \%$ to $99 \%$ and were considered almost accurate. The sequences that have been aligned in CLUSTAL then were activated by using MEGA 4 software to construct phylogeny tree (Figure 3).
The phylogeny tree was constructed to show the relationship and comparison of our marine bacteria sequences data and GenBank sequences. Based on phylogeny tree result, 6 out of 10 strains [F1S, F5S, 1A2H (1), $1 \mathrm{~A} 2 \mathrm{H}(2), \mathrm{E} 3 \mathrm{~B}, \mathrm{~A} 1$ and $\mathrm{C} 1(2)(2)]$ were similar to Shewanella algae strain ATCC 51192 while the other two [C2(2) and E2B] were similar to Shewanella sp. strain W3. All 10 strains were located in the same families which are Shewanellaceae and under phylum Proteobacteria. There are some bacteria from other genus that was put together in this phylogeny tree in order to compare the relationship between isolated species.

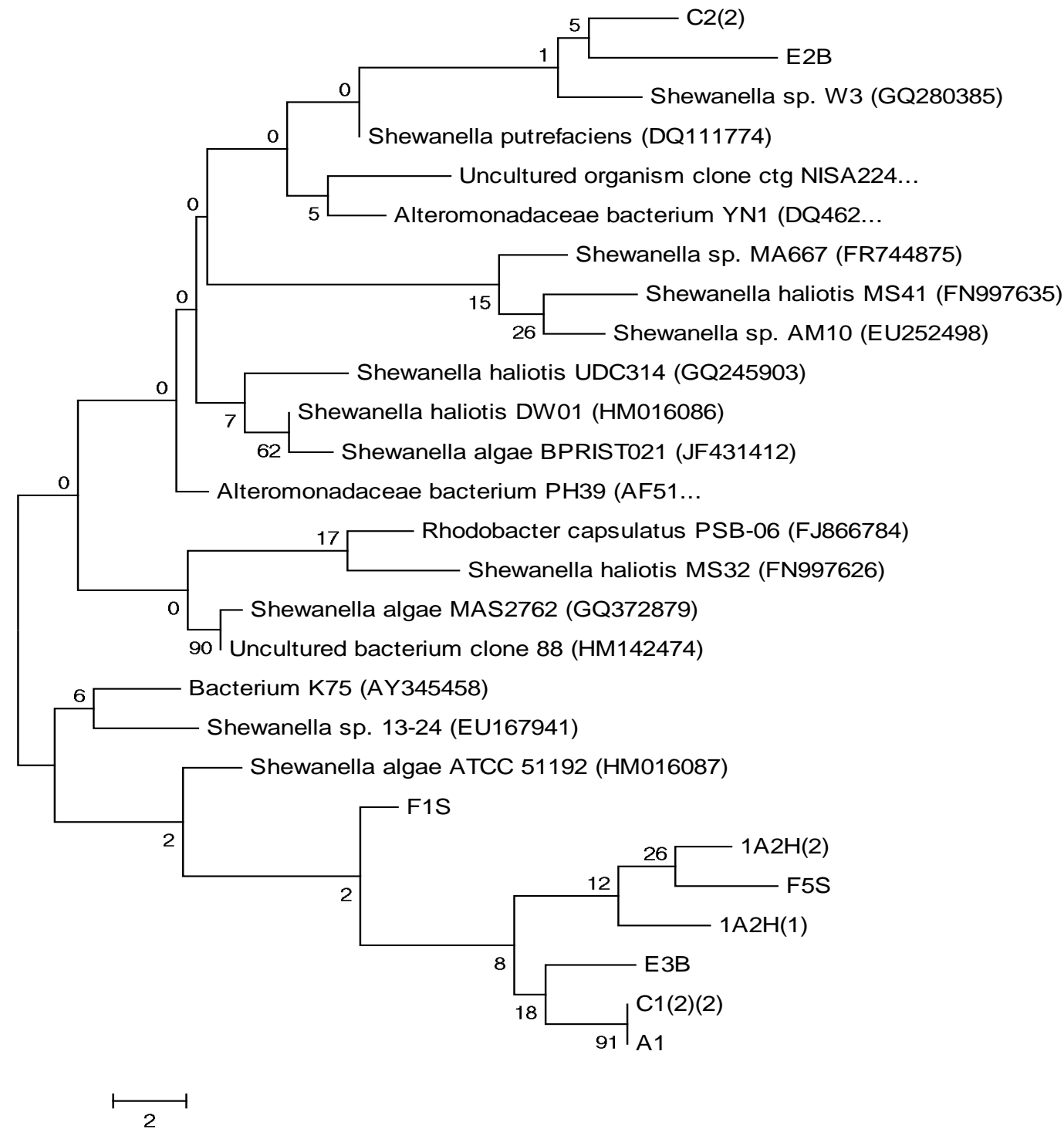

Figure 3: Phylogeny tree based on 16S rRNA gene sequences showing relationships between isolates sequences with GenBank sequences. 


\section{DISCUSSION}

Images from scanning electron micrograph (SEM) can be seen in Figure 1 where images show the growth of biofilm layer and EPS. In this study, the surfaces of stainless steel used for the attachment of IRB are rough and it helps in the formation of biofilm and EPS. When the surface is rough and uneven, it provide shelter space and the wider area to help further the adhesion of bacteria to produce EPS and biofilm and according to Ahimou et al. (2007), the ability of bacteria to produce EPS is depends on the physical of the surface that the bacteria attached whether it is rough and uneven or flat and smooth.

The formation of biofilm and EPS were assisted by several factors and one of them is the presence of oxygen. In this study, IRB were cultured in anaerobic condition before being added with stainless steel coupon and based on the images obtained in Figure 1 shows strains of IRB produces a thick layer of biofilm and it is similar to the study by McLean et al. (2008) which stated that the biofilm formed were structurally packed if Shewanella strain, one of the bacteria belong to IRB group being used. Furthermore, according to Thormann et al. (2005), the removal of oxygen enhances the attachment of bacteria towards any surfaces it attached. Besides that, there are some strains that produce a thin layer of biofilm and EPS and there is possibilities some mistakes occur during the growth of IRB where little amount of oxygen diffuse into the solution. The presences of oxygen causes change to $\mathrm{pH}$, redox and reducing ability and according to Beach et al. (2005), oxygen affects the formation and structure of three dimensional biofilm by Shewanella strains. It is also supported by Lee and Newman (2003), which stated that the presences of other elements including the oxygen could modify the chemical environment and thus accelerate and mitigate the process of corrosion by bacteria.

According to Sacchi (2002), a primer 16S rRNA was used in Polymerase Chain Reaction (PCR) process to estimate the relationship between bacteria and identified unknown bacteria. All types of prokaryotes have this kind of primer in themselves and it would be easier for researcher to conduct research involving identification of bacteria by using 16S rRNA primer. The application of 16S rRNA was very extensive in order to identify bacteria in an open environment including marine environment (Lau et al., 2004). Based on the constructed phylogeny tree (Figure 3), it can be concluded that 6 out of 10 strains were belong to the Shewanellaceae family (Ivanova et al., 2004) and under the class of Gammaproteobacteria (Anzai et al., 2000). These bacteria are able to grow in aerobic and anaerobic conditions and known as facultative anaerobic bacteria, having rod shaped forms and belong to gram negative bacteria and according to Bowman (2005), genus Shewanella comprises of Gram negative, rod shaped, motile and facultative anaerob. These bacteria also have been isolated from different sources including marine environment (Yang et al., 2007) and this has been demonstrated in this study where stainless steel was immersed in Port Dickson seawater for the purpose of bacterial adhesion.

Based on Figure 3, strains E2B and $\mathrm{C} 22$ have similarities with Shewanella algae while strains F1S, $1 \mathrm{~A} 2 \mathrm{H}(1), 1 \mathrm{~A} 2 \mathrm{H}(2), \mathrm{F} 5 \mathrm{~S}, \mathrm{C} 1(2)(2), \mathrm{E} 3 \mathrm{~B}$ and $\mathrm{A} 1$ have similarities with Shewanella putrefaciens. Both species have much in common in terms of producing hydrogen gas, $\mathrm{H}_{2}$, isolated from marine environment with a salinity rate of 15-20 ppt, rod shaped, Gram negative and able to grow on postgate $\mathrm{C}$ medium at $37^{\circ} \mathrm{C}$ (Holt et al., 2005). It has been proved in this study where IRB colonies growth on media agar was stinking due to the presence of hydrogen gas, rod shaped and pink in color after gram staining and growth well in incubator at $37^{\circ} \mathrm{C}$. There are also studies that show both Shewanella algae and $S$. putrefaciens differences in the ability to grow in $6 \% \mathrm{NaCl}$ solution (Khashe and Janda, 1998).

Shewanella sp. is a Gram-negative, biofilm-forming gamma-proteobacterium and most members of Shewanellaceae family are capable of extracellular electron transfer (EET) to reduce insoluble metal oxides and hydroxides as part of their energy conservation energy (Fredrickson et al., 2008; Firer-Sherwood et al., 2008). It is known that marine Shewanella can cause severe damage on metals and the process known as biocorrosion. Bacteria are able to transfer electrons to metals, such as Shewanella shows ability to transfer electrons to metals located $>50 \mu \mathrm{m}$ from cell surfaces (Nevin and Lovely, 2002). The concurrence of Direct Electron Transport (DET) and Mediated Electron Transport (MET) in $S$. oneidensis MR-1 also was extensively proven both in metal reduction and bioelectricity production (Roh et al., 2006).

\section{CONCLUSION}

It can be concluded that most of marine bacteria attached on stainless steel immersed in seawater in this experiment are belongs to Shewanella genus which one of IRB's group and are able to produce biofilm on the surface of stainless steel which can led to biocorrosion process.

\section{REFERENCES}

Ahimou, F., Semmens, M. J., Haugstad, G. and Novak, P. J. (2007). Effect of protein, polysaccharide and oxygen concentration profiles on biofilm cohesiveness. Applied and Environmental Microbiology 73, 29052910.

Anzai, Y., Kim, H. Park, J. Y., Wakabayashi, H. and Oyaizu, H. (2000). Phylogenetic affiliation of the Pseudomonas based on 16S rRNA sequence. International Journal of Systematic and Evolutionary Microbiology 50, 1563-1589.

Beach, S. R., Schulz, R., Williamson, G. M., Miller, L. S., Weiner, M. F. and Lance, C. E. (2005). Risk factor for potentially harmful informal caregiver behavior. Journal of the American Geriatrics Society 53, 255261. 
Bowman, J. P. (2005). Genus XIII. Shewanella, MacDonell and Colwell 1986, 335. In: Bergey's Manual of Systematic Bacteriology, $2^{\text {nd }}$ edition, vol. 2., part B. Brenner, D. J., Krieg, N. R., Staley, J. T. and Garrity, G. M. (Eds.) New York : Springer. pp. 480-491

Firer-Sherwood, M., Pulcu, G. S. and Elliot, S. J. (2008). Electrochemical interrogation of the Mtr cytochromes from Shewanella: opening a potential window, Journal of Biological Inorganic Chemistry 13, 592-603.

Fredrickson, J. K., Romine, M. F., Beliaev, A. S., Auchtung, J. M., Driscoll, M. E., Gardner, T. S., Nealson, K. H., Osterman, A. L., Pinchuk, G., Reed, J. L., Rodionov, D. A., Rodrigues, J. L., Saffarini, D. A., Serres, N. H., Spormann, A. M., Zhulin, I. B. and Tiedje, J. M. (2008). Towards environmental system biology of Shewanella. Nature Reviews Microbiology 6, 592-603.

Holt, H. M., Garhn-Hansen, B. and Bruun, B. (2005). Shewanella algae and Shewanella putrefaciens: clinical and microbiological characteristics. Clinical Microbiology and Infection 11, 347-352.

Ivanova, E. P., Nedashkovskaya, O. I., Sawabe, T., Zhukoya, N. V., Frolova, G. M., Nicolau, D. V., Mikahilov, V. V. and Bowman, J. P. (2004). Shewanella affinis sp. nov., isolated from marine invertebrates. International Journal of Systematic and Evolutionary Microbiology 54, 1089-1093.

Javaherdashti, R. (2008). Microbiologically Influenced Corrosion : An Engineering Insight. Springer-Verlag, London, UK 29-66.

Khashe, S. and Janda, M. J. (1998). Biochemical and pathogenic properties of Shewanella alga and Shewanella putrefaciens. Journal of Clinical Microbiology 36, 783-787.

Landoulsi, J., Elkirat, K., Richard, C., Feron, D. and Pulvin, S. (2008). Enzymatic approach in microbialinfluenced corrosion: A review based on stainless steels in natural waters. Environmental Science \& Technology 42, 2233-2242.

Lau, S. C. K., Tsoi, M. M. Y., Li, X., Plakhotnikova, I., Wu, M., Wong, P. K. and Qian, P. Y. (2004). Loktanella hongkongensis sp. nov. a novel member of the $\alpha$-Proteobacteria originating from marine biofilms in Hong Kong waters. International Journal of Systematic and Evolutionary Microbiology 54, 22812284.

Lee, K. and Newman, D. K. (2003). Microbial iron respiration: Impacts on corrosion processes. Applied Microbiology Biotechnology 62, 134-139.

Lovely, D. R. (1991). Dissimilatory $\mathrm{Fe}(\mathrm{III})$ and $\mathrm{Mn}(\mathrm{IV})$ reduction. Microbiology Review 55, 259-287.

McLean, R. J. C., Ositadinma, N. O. and Major, P. D. (2008). Correlated biofilm imaging, transport and metabolism measurements via combined nuclear magnetic resonance and confocal microscopy. The ISME Journal $2,121-131$.

Myers, C. R. and Nealson, K. H. (1990). Iron reduction by bacteria: A potential role in the genesis of banded iron formations. American Journal of Science 290, 3545.

Nealson, K. H. and Saffarini, D. (1994). Iron and manganese in anaerobic respiration: environmental significance, physiology and regulation. Annual Review of Microbiology 48, 311-343.

Nealson, K. H., Belz, A. and McKee, B. (2002). Breathing metals as a way of life: Geobiology in action. Antoine Leeuwenhoek 81, 215-222.

Nevin, K. P. and Lovely, D. R. (2002). Mechanisms for $\mathrm{Fe}$ (III) oxide reduction in sedimentary environments. Geomicrobiology Journal 19,141-159.

Obuekwe, C. O., Westlake, D. W. S. and Cook, F. D. (1981). Effect of nitrate on reduction of ferric ion by a bacterium isolated from crude oil. Canadian Journal of Microbiology 27, 692-697.

Pukall, R., Kramer, I., Rhode, M. and Stackebrandt, E. (2001). Microbial diversity of cultivable bacteria associated with the North Sea bryozoan Flustra Foliacaea. Systematic and Applied Microbiology 24, 623-633.

Roh, Y., Gao, H., Vali, H., Kennedy, D. W., Yang, Z. K., Gao, W., Dohnalkova, A. C., Stapleton, R. D., Moon, J. W., Phelps, T. J., Fredrickson, J. K. and Zhou, J. (2006). Metal reduction and iron biomineralization by a psychotolerant $\mathrm{Fe}(\mathrm{III})$-reducing bacterium, Shewanella sp. strain PV-4, Applied and Environmental Microbiology 472, 3236-3244.

Semple, K. M. and Westlake, D. W. S. (1987). Characterization of iron-reducing Alteromonas petrafaciens strains from oil field fluids. Canadian Journal of Microbiology 35, 925-931.

Thompson, J. D., Gibson, T. J., Plewniak, F., Jeanmoughin, F. and Higgins, D. G. (1997). The Clustal $X$ windows interface: Flexible strategies for multiple sequence alignment aided by quality analysis tools. Nucleic Acid Research 24, 4876-4882.

Thormann, K. M., Saville, R. M., Shukla, S. and Spormann, A. M. (2005). Induction of rapid detachment in Shewanella oneidensis MR-1 biofilms. Journal of Bacteriology 187, 1014-1021.

Videla, H. A. (1996). Manual of Biocorrosion. CRC Press Incorporation United States of America.

Walch, M. (1992). Microbial corrosion. In: Encyclopedia of Microbiology. Lederberg, J. (Ed.) Academic Press, New York. 1, 585-591.

Yang, H., Hung, T. L., You, T. L. and Yang, T. H. (2006). Genome-wide comparative analysis of the highly abundant transposable element DINE-1 suggests a recent transpositional burst in Drosophila yakuba. Annual Drosophila Research Conference 47, 691.

Yang, K., Ma, W., Liang, H., Ouyang, Q., Tang, C. and Lai, L. (2007). Dynamic simulations on the arachidonic acid metabolic network. PLOS Computational Biology 3, 55 .

Yoon, H. S., Hackett, J. D., Cignilia, C., Pinto, G. and Bhattacharya, D. (2004). A molecular timeline for the origin of photosynthetic eukaryotes. Molecular Biology and Evolution 21, 809-818. 
Xiao, X., Wang, P., Zeng, X., Bartlett, D.H. and Wang, F. (2007). Shewanella psychrophila sp. nov., and Shewanella piezotolerans sp. nov., isolated from west Pacific deep-sea sediment. International Journal of Systematic and Evolutionary Microbiology 57, 60-65.

Zinkevich, V., Bogdarina, I., Kang, H., Hill, M. A. W., Tapper, R. C. and Beech, I. B. (1966). Characterization of exopolimers produced by different isolates of marine sulphate-reducing bacteria. International Biodeterioration and Biodegradation Journal 8, 163-172. 